\title{
FMCG companies specific distribution channels
}

\author{
Teaching assistant Ioana Barin - Olariu, University "Vasile Alecsandri” of Bacau
}

\begin{abstract}
Distribution includes all activities undertaken by the producer, alone or in cooperation, since the end of the final finished products or services until they are in possession of consumers. The distribution consists of the following major components:

- Distribution channels or marketing channels, which together form a distribution network;

- Logistics o rphysical distribution.

In order to effective achieve, distribution of goods requires an amount of activities and operational processes related to transit of goods from producer to consumer, the best conditions, using existing distribution channels and logistics system. One of the essential functions of a distribution is performing acts of sale, through which, with the actual movement of goods, their change of ownership takes place, that the successive transfer of ownership from producer to consumer. This is an itinerary in the economic cycle of goods, called the distribution channel.
\end{abstract}

\section{Keywords}

Distribution channel, direct distribution, indirect distribution, outlets classification.

\section{Intoduction}

Distribution in its general meaning is the physical movement of stock from the place of manufacture to retailer and then in consumer possession.

Distribution is divided in two phases:

- Distribution on the client store;

- Distribution as trade marketing element.

Distribution is vital to the success of FMCG companies. Ensuring that they deliver to customers their brands in the correct amount, the place and right time, in good condition and at a competitive price, is still a challenge for the trade marketing and distribution companies department. Also, the distribution is important for business partners, including independent distributors, the relationship with them based on the principle of mutual profit.

FMCG companies have three objectives in terms of distribution:

- Brands' availability - final consumers can buy the products only if those are on the shelves. The right brands should be in the right outlet at the right time. Brands' disponibility should reflect the customers profile from each area.

- Product's quality - companies must ensure that the consumers have the best products in terms of freshness, appearance package and quality.

- Effective distribution of price viewpoint - making the availability and quality of products in the most effective, has an important role in efficient distribution.

A better distribution helps reduce costs, bad investments in too much stocks of products, increases profits and improves communication for each person involved in the distribution. 
1. Direct distribution or direct delivery to outlets - in this case, the companies control goods distribution directly to retailers or through exclusive distributors.

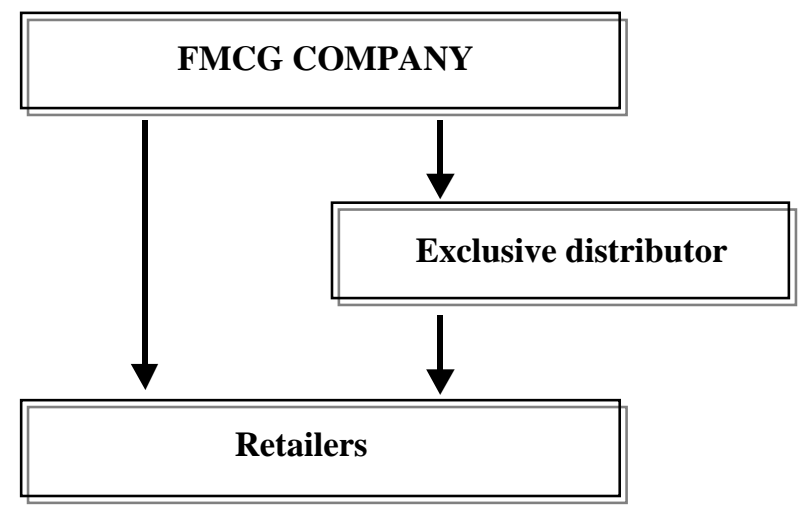

Fig.1. Direct distribution

Direct distribution offers the following mutual benefits:

- A simple and direct distribution line;

- A constant bilateral communication to and from retailers.

Being simple, it reduces the amount of goods that passes through several links and maintains product appearance. Making direct distribution to retailers allow to all those in the supply chain to interact directly.

2. Indirect distribution - it involves an intermediary which delivers the products to retailer. FMCG companies don't control all aspects of brands distribution.

Indirect distribution occurs when it exists the control of the entire supply chain; the control passes to Cash \& Carry wholesaler or retailer so that products are available at the retailer.

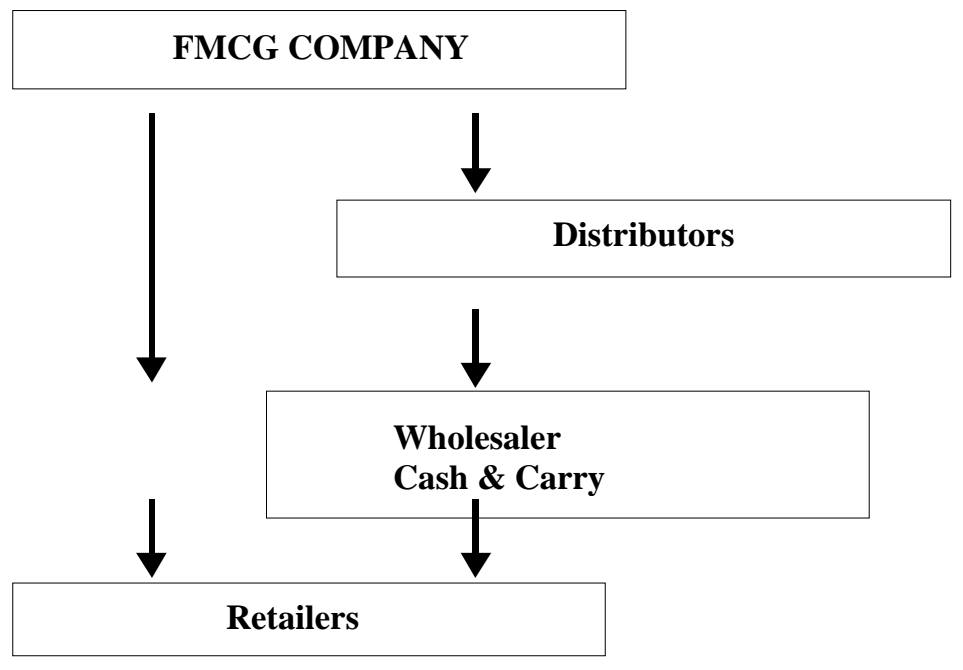

Fig.2. Indirect distribution 
In certain markets, these intermediaries are more specialized. They are focusing their efforts on one particular type of trade channel. A trade channel groups its clients that have similar characteristics, such as:

- The outlet type;

- The range of products;

- The pricing policy;

- The Consumers type;

- The objectives and strategies.

\section{Types of distribution channels}

Similar clients must be grouped into trade channels to allow the specialization of the companies' resources and to better understand clients' business who fit a certain type of trade channel:

- GROCERY outlets;

- CONVENIENCE outlets;

- HoReCa outlets.

3.1. Grocery classification: there are diverse range of goods. In general, buyers come with a list of products, that they buy or search for another person.

\subsubsection{Discounter:}

- The main category of products is represented by "dry" products (canned, sugar, flour, etc.);

- Self-service;

- Reduced range of products: 1-2 brands/ products area;

- Functional sets, non-aesthetic;

- Located in urban areas/residential;

- $\quad$ Trade surface ranged from 300 to $2.500 \mathrm{~m}^{2}$

\subsubsection{Hypermarket:}

- Self-service, with at least 10 pay-desks;

- Key categories are fast moving consumer goods;

- An agressive pricing strategy;

- Located in the coterminous area of cities;

- Trade surface is larger than $2.500 \mathrm{~m}^{2}$.

\subsubsection{General store}

- Counter servicing, with self-service possibility;

- Less than 5 pay-desks;

- The main categories are fast moving consumer goods;

- Usually located in residential areas;

- Trade surface less than $1.500 \mathrm{~m}^{2}$;

- The space is reduced, and the shelves are less organized.

\subsubsection{Supermarket}

- Self-service, with at least 5 pay-desks;

- The basic categories are composed of fresh and dry products;

- Wide range of products;

- Located in urban areas, usually in residential areas;

- Trade surface ranged from 300 to $2.500 \mathrm{~m}^{2}$;

- Well organized by groups of goods arranged on shelves. 
3.2. Convenience classification: it offers specific advantages, such as easily accessible location or an extensive working time table. It sells various product categories, but relatively few types.

\subsubsection{C-store}

- Key categories are the products fated to immediate consumption/needs chips, soft drinks, newspapers, tobacco, sweets;

- Products are available at a cash-register or on self-service; often with a long working time table;

- The prices alters, but tend to be above average level;

- Located near homes, in residential areas;

- $\quad$ Reduced trade surface, in general $-300 \mathrm{~m}^{2}$.

\subsubsection{Kiosk}

- Key categories are sweets, chips, soft drinks, tobacco, newspapers, gifts;

- Variable surface, generally smaller than $50 \mathrm{~m}^{2}$;

- They can work as franchise in the hotels, which can affect the merchandising;

- The lack of space may restrict the merchandising opportunities;

- The key outlets are located in the pedestrian areas, stations and other high traffic areas.

\subsubsection{Gas stations}

- The main purpose is selling fuels, the majority sells even food, sweets, tobacco, newspapers, etc.;

- It often works in a system similar to C-Store;

- $\quad$ Food products are generally sold at high prices;

- Key locations are on the main roads, in both areas, urban and rural;

- Mostly self-service to the cash register.

\subsubsection{Street vendor:}

- It doesn't have a permanent location;

- It sales products for immediate consumption.

3.3. HoReCa classification: are places where the consumer pays for the drink, food, accomodation or entertainment, being liable to an impulse consumption.

\subsubsection{Bar}

- The main categories consist in alcoholic and non-alcoholic immediate consumption;

- The sale is performing either the counter or by a waiter, on which are often adding tobacco products;

- Located in trade or residential areas, both urban and rural;

- A reduced trade surface.

\subsubsection{Recreational}

- Provides recreation and entertainments services;

- The consumer visits these places for relaxation and recreation;

- Located in urban and trade areas. Resorts may be outside the cities, in rural area or near beaches.

\subsubsection{Disco}

- These places begin their activity at dusk, with longer working time table; 
- The main attraction is the music and dance;

- Are marketed alcoholic beverages and tobacco products;

- Merchandising achievements are usually personalized.

\subsubsection{Restaurant}

- Provides a wide range of products that are cooked for immediate consumption;

- The consumer spends a long time in this location;

- It is located in the trade areas/residential (urban/rural);

- It sells a limited range of products, mostly premium brands.

\section{Conclusion}

FMCG companies activate in an environment of increasing complexity of products, rapid technological development and increasing economic, social and political pressures. Strategically oriented companies realize that the key element of long-term success is increasing interdependence. These proactive companies understand that strong long-term profitability can be achieved by creating and promoting positive relationships, mutual benefit between members of distribution channel.

\section{Bibliography}

1. Balaure, Virgil ( coordinator ); Adăscăliței, Virgil; Bălan, Carmen; Boboc, Ştefan; Cătoiu, Iacob; Olteanu, Valerică; Pop, Nicolae Alexandru; Teodorescu, Nicolae (2000 şi 2002), Marketing, Publishing House Uranus, Bucureşti

2. Blythe, Jim (2005), Managementul vânzărilor şi al clienţilor cheie, Publishing House Codecs, Bucureşti

3. Dwyer, F.R.; Tanner, J.F., (2006), Business Marketing, McGrew-Hill, New-York, 3rd edition

4. Gattorna, J.L., (1999), Managementul logisticii si distributiei, Publishing House Teora, Bucuresti

5. Kotler, Philip (1997), Managementul marketingului, Publishing House, Bucureşti

6. www.magazinulprogresiv.ro 